
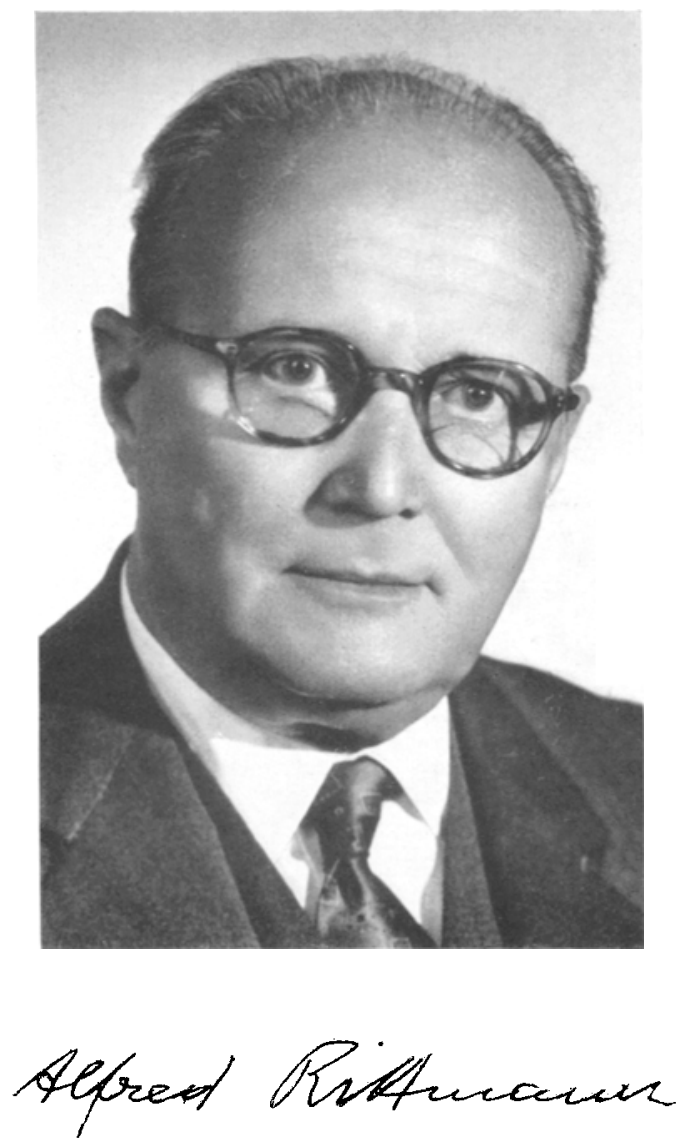

Die Geologische Vereinigung verlieh im Jahre 1965 die Gustav-Steinmann-Medaille

an

\title{
PROFESSOR DR. ALFRED RITTMANN
}

in Würdigung seiner Verdienste um die Erforschung des Vulkanismus 